\title{
Board Characteristics, Dividend Policy and Shareholders' Wealth of Listed Manufacturing Companies in Nigeria
}

\author{
Isa Muhammad Aminu \\ Bayero University, Kano
}

\author{
Aishat Salawudeen \\ University of Abuja
}

This study examines the direct and indirect effect of board characteristics on shareholders' wealth of manufacturing companies in Nigeria using dividend policy as mediator. Study population is six three manufacturing companies listed on the Nigerian stock exchange in 2008 to 2018. Sample of Fifty-one companies were used. Using path analysis, significant impact of dividend payout on BX and SW exist. $B C, B S$, and $B G$ have positive significant effect on $S W$ (EPS and MPS). It's concluded that, board characteristics can improve shareholders wealth by using dividend policy. Therefore, sampled firms can restructure their dividend policies for the improvement of shareholders' wealth.

Keywords: Board Characteristics, Dividend Policy, Mediation, Shareholders' Wealth

\section{INTRODUCTION}

Corporate business environment in Nigeria has experienced cases of damages caused by poor board characteristics which brought about doubts in the mind of the owners and the general public (Uwalomwa, Olamide \& Francis, 2015). Ada (2012) and Shehu (2015) state that poor board character can lead to ineffective boards' decision, especially financial decision which eventually may contribute to the failures of a company. Following the noted poor performance of board of directors, different scandals and failures have occurred in corporations which have negative effect on the returns to shareholders. Aside from the corporation's financial scandals, the board of directors appears to be blame for having the poor performance which in turn affect shareholders' wealth, hence, to improve the wealth of the shareholders' by the boards of directors in the modern days corporations is become an issues, code of corporate governance reform was established to uphold the ethics of corporations (Akande, 2016). In today's modern corporation, the separation of ownership and control mechanism has led to conflict of interest between the owners and managers. Consequently, management follows its own self-interest and involves in activities which reduce the wealth of the stakeholders (Jensen \& Meckling, 1976). Therefore, agency cost will arise and leads to reduction in value of a firm there by reducing the shareholders' wealth.

Board character is substantially central in achieving and maintaining shareholders' trust and confidence especially in financial decision. Yet corporate business environment around the globe has experienced cases of damages caused by poor board characteristics which brought about doubts in the mind of the owners and the general public (Johl, Kaur \& Cooper, 2015). Studies revealed that firms with 
poor board characteristics underperform, which have positive or negative sway on financial decisions which determine the wealth of the shareholders. For instance, Ada (2012) and Shehu (2015) state that poor board character can lead to ineffective boards' decision, especially financial decision which eventually may contribute to the failures of a company. A number of other useful researches such as Azar, Rad and Botyari (2014); Ghabayen (2012); Bathula (2008); Ghosh (2006); Abdullah (2004) examine board characteristics on shareholders' wealth. In other vein, Pelt (2013); Bolbol (2012); Subramaniam and Devi (2011); Yarram (2010) examine board characteristics and dividend payout ratio. While, Omoregie and Eromosele (2016); Chenchehene and Mensah (2015); Kumaresan (2014); Dewet and Mpinda (2013); Elangkumara and Jenitta (2012); Iram (2010) examine dividend policy and shareholders' wealth. These study were conducted to shade light on the relationship between board of directors and shareholders' wealth, board of directors and dividend policy and dividend policy and shareholders' wealth. However, there are still some debates about these associations. Fascinatingly in contrast, these studies have focused on either relationship between board of directors and shareholders' wealth or board of directors and dividend policy or dividend policy and shareholders' wealth at a time. None of these studies considered the influence of the mediating effect of dividend policy on relationship between board characteristics and shareholders' wealth. Therefore board effectiveness is particularly important in the Manufacturing companies in Nigeria because a number of fraudulent and questionable business practices had adversely affected shareholders' wealth. Perhaps this has inform the renewed interest in corporate governance practices particularly board characteristics globally, especially in the Manufacturing sector which play a major role in the development of the country's economy. Thus, the following hypothesis is formulated for testing:

$\boldsymbol{H}_{1}:$ Board characteristics have significance effect on shareholders' wealth of listed manufacturing companies in Nigeria.

$\boldsymbol{H}_{2:}$ Board characteristics have significant effect on dividend policy of listed manufacturing companies in Nigeria

$\boldsymbol{H}_{3}:$ Dividend policy have significance effect on shareholders wealth of listed manufacturing companies in Nigeria.

$\boldsymbol{H}_{4}:$ Dividend policy impact on the relationships between board characteristics and shareholders' wealth of listed manufacturing companies in Nigeria.

\section{LITERATURE REVIEW}

Earnings per share (EPS) is the portion of a company's profit allocated to each outstanding share of common stock. It serves as an indicator of a company's profitability which is normally considered to be the single most important variable in determining a share's price. Though, earnings can cause stock prices to rise, and when they do, investors boost their wealth. Therefore, a review of the relationship between board characteristics and shareholders' wealth is an indication that the predictive ability of board characters to affect shareholders' wealth is relevant to all a sundry. For the purpose of the study Earnings

per share (EPS) and Market Price per Share (MPS) is used to proxy shareholders wealth for comparison.

\section{Board Composition and Shareholders' Wealth}

Non-executive directors are believed to be more independent and are better able to protect the interests of the shareholders (Gosh \& Sirman, 2003). Also, non-executive directors have a reputational risk to protect and they will therefore react differently than executive directors (Fama \& Jensen, 1983). However, studies have also shown that non-executive directors have less firm-specific expertise and knowledge and they spend less time than executive directors, therefore will not be able to make decisions as good as executive directors. Yusoff and Adamu (2012) state that the board of directors bear the 
ultimate responsibility for preventing negative management practices that may lead to corporate failures but also ensure that firms take advantage of opportunities that improve shareholder's wealth. To this end, the board should recognized combine competencies and capabilities towards execution of the governance function. Agency theory advocates the participation of independent non-executive director to promote the independent of the board from the management. The need for the outside directors to contribute their fresh ideas, independent, objectivity, expertise knowledge gained from their own field of endeavor (Borokhovic, Parrino \& Trapani, 1996).

Officer (2011) state that appointing higher percentages of outside directors to the board is associated with increasing its effectiveness in monitoring function of the board. Ghabayen (2012) state that corporations with more effective monitoring of management are less likely to be involved in corporate fraud; also non-executive directors have little incentive to engage in this type of behavior. Beasley (1996) argue that the board composition differ between fraud firms and non-fraud firms. He confirms that the percentage of outside directors on the board of director is lower for fraud firms compared to no-fraud firms in the American context. He also suggests that the inclusion of a high proportion of independent directors prevent fraudulent actions and increase shareholders wealth.

\section{Board Size and Shareholders' Wealth}

The size of the board is the total number of board members comprising executive directors, nonexecutive directors, independent directors and gray directors in a company. Although the size of the board varies across businesses in accordance to the needs and the resources available to the firms to take care of the cost associated with it. However, previous studies have conflicting views about the size of a board and its influence on the corporate decisions. Jensen, (1993) and Lipton and Lorsch (1992) argue that smaller board sizes are more effective monitors. Thus, conclude that firms with the smallest boards have better monitoring abilities and can take strategic financial decision. Beasley (1996) indicates that the likelihood of financial statement fraud increases is in larger boards.

\section{Board Ownership and Shareholders' Wealth}

Agency theory indicates that the goals of the managers, who are pursuing their self-interest, are not aligned with the goals of the owner of the company, the shareholder. Because managers know more about the company than the shareholder, information asymmetry arises (pelt, 2013). This information asymmetry will make managers able to chase their own goals, which comes at a cost, the agency cost (Jensen \& Meckling, 1976). However, in order to align interest of both parties, directors are given shares, stock option, and compensation. Director equity ownership is an incentive to directors to enable them monitor managers effectively (Pelt, 2013). Bathula (2008). argue that when directors own shares in the company, they will like to take actions that will increase both their wealth and that of the shareholders. However, the fraction of equity held by the board of directors will yield better result in terms of the going concern. This is because as the directors own part of the company, their interests is expected to align with the interest of the shareholders in order to reduce agency costs (Ghosh \& Sirmans, 2006). However, when directors have a large part of shares, takeover threat will reduce and directors will get entrenched (Morck, Shleifer \& Vishny, 1988).

\section{Board Gender Diversity and Shareholders' Wealth}

As agency theory states that board gender diversity enhances the board's ability to monitor top management. Therefore, increase in the number of female directors may increase board's independence since woman have the tendencies to ask questions than their male counterparts. Carter, Simkins and Simpson (2003) indicate that women are more risk averse than men, particularly in certain economic conditions, and they are less involved than men in unethical conducts. However, Board gender has been associated with firm's tendency to pay or increase dividend because when board is diversified with female directors, strategy decision will be less aggressive and more risk averse. Marinova, Plantenga and Remery (2010) reveal that if the fraction of women on the board is few, there will be a negative effect on 
shareholders' wealth owing to ineffective financial decisions. If the percentage of women on the board increases, it will be advantageous as this will improve the effectiveness of the board's decisions.

\section{REVIEW OF EMPIRICAL STUDIES}

\section{Board Composition and Earnings per Share}

Yusoff and Adamu (2012) examine the relationship between non-executive independence directors on earnings per share in Malaysia. The study used a sample of 813 listed companies on Bursa Malaysia. Data were collected from the annual report for a period of three years from 2009 to 2011. Correlational analysis was used to test the hypotheses on the relationships between non-executive independence director and earnings per share. The result provide positive significant association between non-executive independence directors on earnings per share. Similarly, Adebayo, Ayeni and Oyewole (2013) examine the relationship between board independence on earnings per share in Nigeria non-financial companies. The study used a sample of 30 listed manufacturing firms, financial and service institutions. Data were collected from the annual report for a period of six years from 2005 to 2010. Multiple regression technique was employed to analyze the effect of board independence on earnings per share. The result provide significant and positive support on the effect of board independence and earnings per share. In addition, Meyer and Wet (2014) assess the relationship between board non-executive and earnings per share in South Africa. The study used a sample of 126 selected listed South African companies. Data were collected from the annual report for a period of three years from 2010 to 2012. Multiple regression technique was employed to analyze the effect of board non-executive on earnings per share. The result provide significant and positive support on the effect of board non-executive on earnings per share.

Contrary to the above studies is Azeez (2015) who examine the relationship between board independence on earnings per share in Sri Lanka. The study used a sample of 100 listed companies in the Colombo Stock Exchange. Data were collected from the annual report for a period of three years from 2010 to 2012. Multiple regression technique was employed to analyze the effect of board independence on earnings per share. The result provide significant but negative support on the effect of board independence and earnings per share. Also, Ayesha, Chathurika, Kumarihami, Sagarika, Nanayakkara and Abeywardane (2015.) examine the relationship between board non-executive independence on earnings per share in Sri Lanka. The study used a sample of 26 listed manufacturing companies in the Colombo Stock Exchange. Data were collected from the annual report for a period of six years from 2009 to 2014. Multiple regression technique was employed to analyze the effect of board non-executive independence on earnings per share. The result provide significant but negative support on the effect of board independence and earnings per share.

However, Ahmad and Hamdan (2015) examine the impact of board independence on earnings per share in Bahrain. The study used a sample of 42 listed companies in Bahrain Stock Exchange database. Data were collected from the annual report for a period of five years from 2007 to 2011. Multiple regression technique was used to analyze the effect of board independence on earnings per share. The result provide negative insignificant support on the effect of board independence directors on earnings per share. Likewise, Faramarzi and Amini (2016) examine the relationship between board independence on earnings per share in Tehran. The study used a sample of 109 companies that are listed on the Tehran Stock Exchange. Data were collected from the annual report for a period of eight years from 2005 to 2012. Multiple regression technique was employed to analyze the effect of board independence on earnings per share. The result provide insignificant and negative support on the effect of board independence and earnings per share.

\section{Board Size and Earnings per Share}

Malik, Wan, Ahmad, Naseem and Rehman (2014) investigate the relationship between board size on earnings per share in Pakistan companies. The study used a sample of selected firms listed on the Karachi stock exchange. Data were collected from the annual report of the companies for a period of five years from 2008 to 2012. Linear regression analysis was used as the method of data analysis. The result provide 
significant and positive effect of board size on earnings per share. Haider, Khan, Al-Sufy and Iqbal (2015) examine the relationship between board size on earnings per share in Pakistan companies. The study used a sample of selected firms listed on the Pakistan stock exchange. Data were collected from the annual report of the companies for a period of five years from 2008 to 2012. Multiple regression analysis was used as the method of data analysis. The result provide significant and positive effect of board size on earnings per share. Sayumwe and Amroune (2015) examine the relationship between board size on earnings per share in Canada. The study used a sample of 36 Canadian companies that are listed on the Toronto Stock Exchange. Data were collected from the annual report for a period of three years from 2011 to 2013. Multiple regression technique was employed to analyze the effect of board size on earnings per share. The result provide significant and positive support on the effect of board size on earnings per share.

On the contrary, Cheema and Din (2013) investigate the relationship between board size on earning per share in Pakistan. The study used a sample of 15 listed cement industries on the Karachi stock exchange. Data were collected from the annual report of the companies for a period of five years from 2007 to 2011. Multiple regression analysis was used as the method of data analysis. The result provide insignificant and negative support on the relationship between board size on earning per share. Confirming the above result was Ahmad and Hamdan (2015) who examine the impact of board size on earnings per share in Bahrain. The study used a sample of 42 listed companies in Bahrain Stock Exchange database. Data were collected from the annual report for a period of five years from 2007 to 2011. Multiple regression technique was used to analyze the effect of board size on earnings per share. The result provide negative insignificant support on the effect of board size on earnings per share. Azeez (2015) examine the relationship between board size on earnings per share in Sri Lanka. The study used a sample of 100 listed companies in the Colombo Stock Exchange. Data were collected from the annual report for a period of three years from 2010 to 2012. Multiple regression technique was employed to analyze the effect of board size on earnings per share. The result provide insignificant but negative support on the effect of board size and earnings per share.

\section{Board Ownership and Earnings per Share}

Meyer and Wet (2014) assess the relationship between board ownership and earnings per share in South Africa. The study used a sample of 126 selected listed South African companies. Data were collected from the annual report for a period of three years from 2010 to 2012. Multiple regression technique was employed to analyze the effect of board ownership on earnings per share. The result provide significant and positive support on the effect of board ownership on earnings per share. Contrary to above is Afhraf Iqbal \& Tariq (2017) who examine the relationship between board ownership on earnings per share in Nigeria. The study used a sample of 23 microfinance banks in Nigeria. Data were collected from the annual report for a period of three years from 2011 to 2013. Multiple regression technique was employed to analyze the effect of board composition on earnings per share. The result provide insignificant and negative support on the effect of board independence and earnings per share. However, Chandren, Ahmad and Ali (2015) examine the relationship between managerial ownership on earnings per share in Pakistan. The study used a sample of 220 listed manufacturing firms, financial and service institutions. Data were collected from the annual report for a period of eight years from 2001 to 2008. Multiple regression technique was employed to analyze the effect of managerial ownership on earnings per share. The result provide insignificant and positive support on the effect of managerial ownership and earnings per share.

\section{Board Gender and earnings per share}

Sayumwe and Amroune (2015) examine the relationship between board gender on earnings per share in Canada. The study used a sample of 36 Canadian companies that are listed on the Toronto Stock Exchange. Data were collected from the annual report for a period of three years from 2011 to 2013. Multiple regression technique was employed to analyze the effect of board gender on earnings per share. The result provide significant and positive support on the effect of board gender on earnings per share. 
Similarly, Shittu, Ahmad and Ishak (2016) study when they examine the relationship between board gender on earnings per share in Malaysia. The study used a sample of full-pledged Islamic banks in Malaysia. Data were collected from the annual report for a period of six years from 2010 to 2015. Multiple regression technique was employed to analyze the effect of board gender on earnings per share. The result provide significant but positive support on the effect of board gender and earnings per share. On the contrary, Ayesha, Chathurika, Kumarihami, Sagarika, Nanayakkara and Abeywardane (2015) examine the relationship between board gender on earnings per share in Sri Lanka. The study used a sample of 26 listed manufacturing companies in the Colombo Stock Exchange. Data were collected from the annual report for a period of six years from 2009 to 2014. Multiple regression technique was employed to analyze the effect of board gender on earnings per share. The result provide significant and negative support on the effect of board gender and earnings per share.

\section{Board Composition and Market Price per Share}

Samontaray (2010) examines the relationship between board characteristics on market price per share in India. The study used a sample of 50 listed companies in the Indian Stock Exchange. Data were collected from the annual report of these companies for a period of three years from 2007 to 2008. Regression analysis technique was employed to analyze the effect of board characteristics on market price per share. The result provide positive significant support on the effect of board composition on market price per share. Sayumwe and Amroune (2017) examine the relationship between board compositions on market price per share in Canada. The study used a sample of 50 Canadian companies that are listed on the Toronto Stock Exchange. Data were collected from the annual report for a period of five years from 2009 to 2013. Regression analysis technique was employed to analyze the effect of board compositions on market price per share. The result provide significant and negative support on the effect of board compositions directors on market price per share. Similarly, Dobbin and Jung (2008) examine the relationship between board compositions on the market price per share in United State companies. The study used a sample of 432 United State companies. Data were collected from the annual report for a period of nine years from 1997 to 2005. Ordinary least square method of estimation was use to estimate the effect of board compositions on market price per share. The result provide significant and negative support on the relationship between board compositions on the market price per share. However, Ferrer and Banderlipe, (2012) examine the relationship between board compositions on the market price per share in Philippines companies. The study used a sample of 29 Philippines companies. Regression analysis method of estimation was use to estimate the effect of board compositions on market price per share. The result provide insignificant effect of board compositions on the market price per share.

\section{Board Size and Market Price per Share}

Sayumwe and Amroune (2017) examine the relationship between board size on market price per share in Canada. The study used a sample of 50 Canadian companies that are listed on the Toronto Stock Exchange. Data were collected from the annual report for a period of five years from 2009 to 2013. Regression analysis technique was employed to analyze the effect of board size on market price per share. The result provide significant and positive support on the effect of board size on market price per share. Similarly, Dobbin and Jung (2008) examine the relationship between board size on the market price per share in United State companies. The study used a sample of 432 United State companies. Data were collected from the annual report for a period of nine years from 1997 to 2005. Ordinary least square method of estimation was use to estimate the effect of board size on market price per share. The result provide significant and positive support on the relationship between board size on the market price per share. However, Ferrer and Banderlipe, (2012) examine the relationship between board size on the market price per share in Philippines companies. The study used a sample of 29 Philippines companies. Regression analysis method of estimation was use to estimate the effect of board size on market price per share. The result provide insignificant effect of board size on the market price per share. 


\section{Board Ownership and Market Price per Share}

Sayumwe and Amroune (2017) examine the relationship between board ownership on market price per share in Canada. The study used a sample of 50 Canadian companies that are listed on the Toronto Stock Exchange. Data were collected from the annual report for a period of five years from 2009 to 2013. Regression analysis technique was employed to analyze the effect of board ownership on market price per share. The result provide significant and positive support on the effect of board ownership directors on market price per share. Similarly, However, Ferrer and Banderlipe, (2012) examine the relationship between board ownership on the market price per share in Philippines companies. The study used a sample of 29 Philippines companies. Regression analysis method of estimation was use to estimate the effect of board ownership on market price per share. The result provide insignificant effect of board ownership on the market price per share.

\section{Board Gender and Market Price per Share}

Ferrer and Banderlipe, (2012) examine the relationship between board gender on the market price per share in Philippines companies. The study used a sample of 29 Philippines companies. Regression analysis method of estimation was use to estimate the effect of board gender on market price per share. The result provide positive significant effect of board gender on the market price. Similarly, Ferrari, Ferraro, Profeta \& Pronzato (2018) examine the relationship between board gender on the market price per share in Germany. The study used a sample of 245 United State companies. Data were collected from the annual report for a period of four years from 2011 to 2014. Ordinary least square method of estimation was use to estimate the effect of board gender on market price per share. The result provide a positive significant support on the relationship between board gender on the market price per share. However, Dobbin and Jung (2008) examine the relationship between board gender on the market price per share in United State companies. The study used a sample of 432 United State companies. Data were collected from the annual report for a period of nine years from 1997 to 2005. Ordinary least square method of estimation was use to estimate the effect of board gender on market price per share. The result provide a negative significant support on the relationship between board gender on the market price per share.

\section{Summary Statistics}

Correlational and explanatory research design will be used for this study. This study is based on the functional/ positivist paradigm. As the study is quantitative in nature and it will use secondary sources of data. The data were collected from the annual reports and financial statement of the sampled listed manufacturing companies filed with SEC and NSE. The population of this study covers the manufacturing companies listed on the Nigerian stock exchange as at $31^{\text {st }}$ December, 2008 up till 2018. This study sampled listed manufacturing companies on stratified random sample due to similarity in their assets allocation from other sectors. Thus, the strata are formed based on five key sectors having common characteristics

TABLE 3.1

\section{SECTOR WISE CLASSIFICATION (2008-2018)}

\begin{tabular}{|l|l|l|l|l|}
\hline S/No & Name of the Sector & No. Companies & Excluded Companies & Study Sample \\
\hline 1 & Conglomerates & 6 & 0 & 6 \\
\hline 2 & Consumer goods & 26 & 3 & 23 \\
\hline 3 & $\begin{array}{l}\text { Construction and Real } \\
\text { Estates }\end{array}$ & 7 & 3 & 4 \\
\hline 4 & Industrial Goods & 19 & 5 & 14 \\
\hline 5 & Natural Resources & 5 & 1 & 4 \\
\hline & Total & 63 & 12 & 51 \\
\hline
\end{tabular}

Source: Generated by the Researcher

30 Journal of Applied Business and Economics Vol. 21(9) 2019 
TABLE 3.2

\section{DEFINITION AND MEASUREMENT OF DEPENDENT, INDEPENDENT AND} MEDIATION VARIABLES

\begin{tabular}{|l|l|}
\hline Variable & \multicolumn{1}{|c|}{ Operationalization } \\
\hline $\begin{array}{l}\text { Earnings per Share } \\
\text { (EPS) }\end{array}$ & $\begin{array}{l}\text { Earnings per share (EPS) is calculated as profit after tax divided by no of shares } \\
\text { outstanding as used by Kai, Shyuan, Yer, Yee and Lai (2014), Gejalakshmi and } \\
\text { Azhagaiah (2015) }\end{array}$ \\
\hline $\begin{array}{l}\text { Market Price Per } \\
\text { Share } \\
\text { (MPS) }\end{array}$ & $\begin{array}{l}\text { Opening price of the year plus the ending price of the year (average stock price) } \\
\text { divided by 2 as used by SabariPriya and Azhagaiah 2008, Khan (2009). }\end{array}$ \\
\hline $\begin{array}{l}\text { Board Composition } \\
\text { (BC) }\end{array}$ & $\begin{array}{l}\text { Ratio of non-executive directors to the total directors on the board as used by Ada } \\
\text { (2013), Shehu (2015), Ikunda, Muiru and Kariman (2016) }\end{array}$ \\
\hline Board Size (BS) & $\begin{array}{l}\text { Number of directors on the board as used by Pelt (2013), Batool and Javid (2014), } \\
\text { Shehu (2015) }\end{array}$ \\
\hline $\begin{array}{l}\text { Board Ownership } \\
\text { BO) }\end{array}$ & $\begin{array}{l}\text { Proportion of shares by the board of directors to as used by Kumar (2006), } \\
\text { Hommel (2011), Daradkah and Ajlouni (2013) }\end{array}$ \\
\hline Board Gender (BG) & $\begin{array}{l}\text { Proportions of female director to size of the board as used by Bolbol (2012), } \\
\text { Harvath and Spirollari (2012) and Dao, Brown and Hsu (2016) }\end{array}$ \\
\hline $\begin{array}{l}\text { Mediating Variables } \\
\text { ratio }\end{array}$ & $\begin{array}{l}\text { Dividend payout ratio is calculated as dividend per share is divided by earnings } \\
\text { per share as used by Suwabe (2006), Mokaya, Nyang'ara and James (2013) } \\
\text { Gejalakshmi and Azhagaiah (2015). }\end{array}$ \\
\hline $\begin{array}{l}\text { Dividend per Share is measured as earnings paid to shareholder (dividend) divided } \\
\text { (DPS) } \\
\text { No. of shares outstanding as sued by Bawa \& Kaur (2013), Ponsian, Prosper, } \\
\text { Yuda and Samuel (2015) and Vasantha (2016). }\end{array}$ \\
\hline $\begin{array}{l}\text { Dividend Yield } \\
\text { (DY) } \\
\text { share as used by Wet and Mpinda (2013), Al-Masum (2014) and Bilal and Jamil } \\
\text { (2015). }\end{array}$ \\
\hline
\end{tabular}

Source: Generated from the review of literature

\section{TECHNIQUES OF DATA ANALYSIS}

\section{Path Analysis Model}

To determine the variability of dependent variable caused by changes in any of the independent variables. Path analysis will be used in this study. Path analysis is basically designed for panel data which were collected for same individual more than one times. As path analysis is widely used to conclude causal relationship in the data from longitudinal research design. For this study, data sets are analyzed through STATA 13.0 and structural equation modeling (SEM) will be used to test the hypothetical relationships between the variables. Thus, in line with the previous studies, such as Ali and Liu (2017), Li and $\mathrm{He}$ (2013), Hu, Tan and Tan (2010) and Lu (2009) and similar studies. The model is specify as follows: 


\section{PATHWAY OF MEDIATION PROCESS FOR BOARD CHARACTERISTICS AND SHAREHOLDERS' WEALTH}

FIGURE 1

\section{HYPOTHESIZED MEDIATIONAL MODEL STRUCTURE}

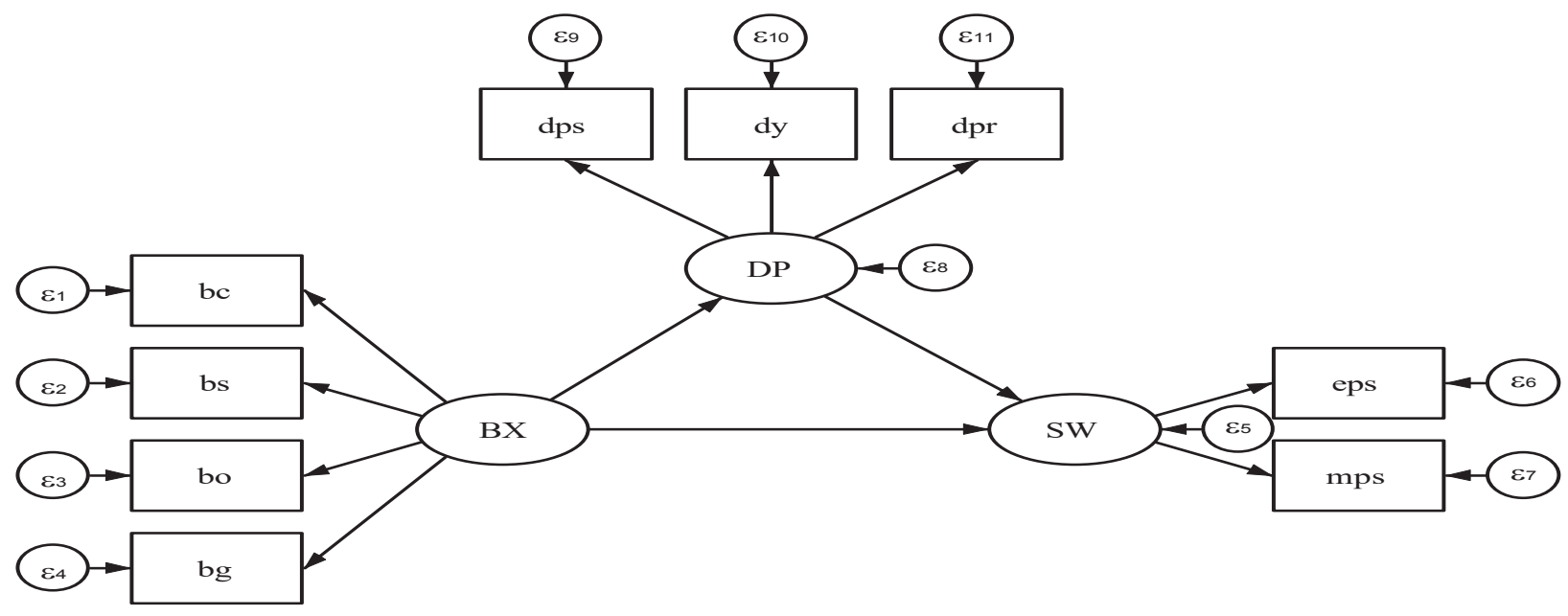

\section{Model Specification}

The first hypothesis influence of independent variables, board characteristics measures (BC) on dependent variables, shareholders' wealth (SW) would be measured through:

Hypothesis $2: \mathrm{BC} \rightarrow \mathrm{SW} \quad \mathrm{SW}=\beta_{0}+(\mathrm{BC})_{1} \beta_{1}+\varepsilon_{\mathrm{i}}$

The second hypothesis influence of independent variables, board characteristics measures (BC) on dependent variables, dividend policy (DP) would be measured through:

Hypothesis $1: \mathrm{BC} \rightarrow \mathrm{DP} \quad \mathrm{DP}=\beta_{0}+(\mathrm{BC}){ }_{1} \beta_{1}+\varepsilon_{\mathrm{i}}$

The third hypothesis influence of independent variables, dividend policy measures (DP) on dependent variables, shareholders' wealth (SW) would be measured through:

Hypothesis 3: DP $\rightarrow \mathrm{SW} \quad \mathrm{SW}=\beta_{0}+(\mathrm{DP}){ }_{1} \beta_{1+}+\varepsilon_{\mathrm{i}}$

While the effects of board characteristics, dividend policy on shareholders wealth would be calculated through:

Hypothesis $4: \mathrm{BC} \rightarrow \mathrm{DP} \rightarrow \mathrm{SW} \quad \mathrm{SW}=\beta_{0}+(\mathrm{BC})_{1} \beta_{1+}(\mathrm{DP})_{2} \beta_{2}+\varepsilon_{\mathrm{i}}$

\section{RESULT AND DISCUSSION}

\section{Descriptive Statistics}

The descriptive statistics is presented in Table 4.1 showing the mean, standard deviation, minimum and maximum of the data in respect of the variables used in the study. 
TABLE 4.1

DESCRIPTIVE STATISTICS

\begin{tabular}{|l|l|l|l|l|l|l|l|}
\hline Variables & Mean & Std Dev & Min & Max & Skewness & Kurtosis & Obs \\
\hline EPS & 2.1844 & 7.8722 & -25.56 & 106.397 & 0.0000 & 0.0000 & 561 \\
\hline MPS & 36.8355 & 124.2353 & 0.25 & 1182 & 0.0000 & 0.0000 & 561 \\
\hline DPR & 0.9034 & 3.6547 & 0.0389 & 47.8789 & 0.0000 & 0.0000 & 561 \\
\hline BC & 0.5223 & 0.2865 & 0 & 1.125 & 0.0000 & 0.0000 & 561 \\
\hline BS & 8.7558 & 2.6463 & 4 & 18 & 0.0000 & 0.4919 & 561 \\
\hline BO & 0.2181 & 0.2109 & 0 & 0.9545 & 0.0000 & 0.0000 & 561 \\
\hline BG & 0.0729 & 0.1055 & 0 & 0.6 & 0.0000 & 0.0000 & 561 \\
\hline DPS & 1.0540 & 4.4505 & 7.9881 & 41.9519 & 0.0000 & 0.0000 & 561 \\
\hline DY & 0.8489 & 7.0854 & 0.0073 & 95.7577 & 0.0000 & 0.0000 & 561 \\
\hline
\end{tabular}

Source: Descriptive Statistics Result Using STATA 13

Table 4.1 shows the average of a company's profit allocated to each outstanding share of common stock for all the sampled manufacturing companies in Nigeria over eleven year period is N2.18k. This indicates low profitability by the sampled firms which means less money available to be distributed to shareholders as dividend. The standard deviation of 7.87 implies that there is no significant variation in Earnings per Share amongst the sampled firms during the period of study. The minimum value of earning per share is -N25.56K implying significant losses in earnings experience in some companies during the period of study with a maximum earnings of N106.40k. Earnings per Share as dependent variable fluctuate. More so, the sample firms have different earnings and heterogeneous, hence, reason for the gap between the minimum value (-N25.56k) and maximum value N106.40K of the Earnings per Share.

The average share price which investors are willing to pay for one share of the sampled manufacturing companies in Nigeria over eleven year period is N36. 84k implying that investment in the sampled firms may be worthwhile. The standard deviation is 124.34 implying the data points are spread out over a large range of values N1,181.75k, the difference between the minimum and the maximum values of $-\mathrm{N} 0.25 \mathrm{k}$ and N1, 182. The market price per share as dependent variable to be stable. More so, the sample firms different share prices and heterogeneous nature could also explain the wide range.

The average portion of a company's profit to be allocated to each common stockholders for all the sampled manufacturing companies in Nigeria over eleven year period was N0.90k. This indicates that the dividend payout ratio was $90 \%$ for all sampled manufacturing companies. Meaning for every naira the companies earns in net income $0.90 \mathrm{k}$ were returned to shareholders as dividend. The standard deviation of 3.65 implies that there is significant variation in dividend payout ratio amongst the sampled firms during the period of study. The minimum value of dividend payout ratio was $-\mathrm{N} 0.04 \mathrm{k}$ implying significant losses in earnings experience in some companies during the period of study with a maximum earnings of N47.88k.

The mean of the board composition of the sampled manufacturing companies for the eleven years period is 0.52 , meaning that the percentage average of non-executive directors to the total number of directors is $52 \%$. The remaining 48 of the board denotes executive directors implying that the majority of the sampled manufacturing companies have more non-executive directors than executive directors on board. It further reveals the important role played by the non-executive directors on the board. The standard deviation of 0.29 indicates that there is no significant deviation among the sampled companies with regards to the number of non-executive directors and executive directors siting on the board The minimum value is zero while the maximum of one.

The average board members on the board of sample manufacturing companies is about 9 members. The standard deviation of 2.65 shows that there is significant variation on the board size of the sampled companies. The minimum value of board size is four (4) and maximum value of eighteen (18) indicating 
that the sampled manufacturing companies records four as the lowest numbers of board members on the board, while the maximum members is eighteen.

The average percentage of share held board of directors of the sampled manufacturing companies for the eleven years period was 0.22 meaning that the directors of the manufacturing companies have ownership incentives of about $22 \%$. The standard deviation of 0.21 indicates that there is no significant variation among the sampled companies with regards to board ownership with minimum value stands at zero while the maximum 0.95 indicating that the lowest percentage of shares held by board of directors is zero and the highest of shares held by board of directors was $95 \%$.

The mean of women directors of the sampled manufacturing companies for the eleven years period was stands at 7, implying that on the average sampled manufacturing companies have $7 \%$ women representative on the board of directors. The standard deviation was 0.11 lower than the mean, indicating much variation of the data points amongst the sampled companies. The minimum value was zero while the maximum 0.6 indicating that within the study period some sampled manufacturing companies do not have women on their board. On the other hand, some sampled manufacturing companies do have $60 \%$ women sitting on their board.

The average returns to the shareholders for all the sampled manufacturing companies in Nigeria over eleven year period is $\mathrm{N} 1.05 \mathrm{k}$ indicating regular financial returns to the shareholders after buying shares in the sampled companies. The standard deviation of 4.45 implies that there is no significant variation in Dividend per share amongst the sampled firms during the period of study. The minimum value of dividend per share is $\mathrm{N} 7.99 \mathrm{~K}$ implying low dividend payment in some companies during the period of study with a maximum of $\mathrm{N} 41.95 \mathrm{k}$.

The average portion of dividend yield for all the sampled manufacturing companies in Nigeria over eleven year period was 0.85 . This indicates that sampled companies were able to payout $85 \%$ in dividend each year in relation to share price. The standard deviation of 7.09 implies that there is variation in dividend yield amongst the sampled firms during the period of study. The minimum value of dividend yield is N0.007k implying that some companies during the period of study have as low as $0.7 \%$ cash flow arisen from units invested in stock, while the maximum yield was 95.76 implying highest cash flow from units invested in stock. 
TABLE 4.2

CORRELATION MATRIX OF COEFFICIENTS OF SEM MODEL

\begin{tabular}{|c|c|c|c|c|c|c|c|c|}
\hline e (V) & $\begin{array}{l}\text { Eps } \\
\text { dps }\end{array}$ & $\mathrm{bc}$ & bs & Bo & bg & Dpr & dy & \\
\hline $\begin{array}{c}\text { Eps } \\
\text { Dps }\end{array}$ & 1.0000 & & & & & & & \\
\hline $\mathrm{Bc}$ & -0.1112 & 1.0000 & & & & & & 1.19 \\
\hline Bs & -0.0263 & -.07883 & 1.0000 & & & & & 1.18 \\
\hline Bo & -.01017 & 0.1686 & -0.4986 & 1.0000 & & & & 1.09 \\
\hline $\mathrm{Bg}$ & -0.0891 & 0.0388 & -0.2653 & 0.0020 & 1.0000 & & & 1.03 \\
\hline $\mathrm{dpr}$ & -0.4479 & 0.0933 & -0.1253 & 0.1257 & -0.0049 & 1.0000 & & 1.40 \\
\hline Dy & -0.9649 & 0.0748 & 0.0451 & 0.1013 & 0.0992 & 0.3648 & 1.0000 & 1.08 \\
\hline e (V) & $\begin{array}{c}\text { mps } \\
\text { eps }\end{array}$ & dps & $\mathrm{bc}$ & bs & bo & $\mathrm{Bg}$ & dy & \\
\hline $\begin{array}{l}\text { Mps } \\
\text { eps }\end{array}$ & 1.0000 & & & & & & & \\
\hline $\mathrm{dps}$ & -0.6974 & 1.0000 & & & & & & \\
\hline $\mathrm{Bc}$ & 0.2172 & -0.2293 & 1.0000 & & & & & \\
\hline Bs & -0.2040 & 0.1238 & -0.7976 & 1.0000 & & & & \\
\hline Bo & 0.0048 & -0.0762 & 0.1656 & -0.4891 & 1.0000 & & & \\
\hline $\mathrm{Bg}$ & 0.0097 & -0.0707 & 0.0351 & -0.2617 & 0.0021 & 1.0000 & & \\
\hline $\mathrm{dpr}$ & 0.6683 & -0.7048 & 0.2129 & -0.2276 & 0.0967 & 0.0028 & 1.0000 & \\
\hline Dy & 0.4669 & -0.9371 & 0.1660 & -0.0562 & 0.0918 & 0.0922 & 0.5520 & 1.0000 \\
\hline e (V) & $\begin{array}{c}\text { Dps } \\
\text { bc }\end{array}$ & bs & Bo & bg & & & & \\
\hline $\begin{array}{c}\text { dps } \\
\text { bc }\end{array}$ & 1.0000 & & & & & & & \\
\hline Bs & -08013 & 1.0000 & & & & & & \\
\hline Bo & 0.1613 & -0.5001 & 1.0000 & & & & & \\
\hline $\mathrm{Bg}$ & 0.0313 & -0.2817 & -0.0041 & 1.0000 & & & & \\
\hline
\end{tabular}

Source: Correlation Matrix of coefficients of SEM Using STATA 13

Table 4.2, Earnings per share is $11 \%$ negatively correlated with board composition. And board size, board ownership, board gender, dividend payout ratio and dividend yield have negative correlation with earnings per share is at the values of $3 \%, 10 \%, 9 \%, 45 \%$ and $96 \%$ respectively. Board size has negative correlation with board composition at $79 \%$, while board ownership, board gender, dividend payout ratio and dividend yield have weak but positive correlation with board composition at $17 \%, 3 \%, 9 \%$ and $7 \%$ respectively. However, the relationship of market price per share with board composition, board ownership, board gender, dividend payout ratio, dividend yield are positive and weak, with the exception of dividend payout ratio which have strong relationship at the values of $22 \%, 4.8 \%, 10 \%, 67 \%$ and $47 \%$ respectively. But, board size and dividend per share have negative association at the value of $70 \%$ and $20 \%$ respectively. However, the relationship of dividend per share with board composition, board ownership, board gender, dividend payout ratio, dividend yield are negatively correlated, with the exception of board size which have positive but relationship at the values of $22 \%, 12 \%, 8 \%, 7 \%$ and $94 \%$ respectively. Moreover, dividend per share has negative relationship with board size at the value of $80 \%$, while, board ownership and board gender have positive and weak relationship at $16 \%$ and $3 \%$ respectively. 
TABLE 4.3

ESTIMATED PATH ANALYSIS OF LISTED MANUFACTURING COMPANIES

\begin{tabular}{|c|c|c|c|c|c|c|c|c|c|c|}
\hline & \multicolumn{4}{|c|}{ Relationship Direct Effect } & \multicolumn{3}{|c|}{ Indirect Effect } & \multicolumn{3}{|c|}{ Total Effect } \\
\hline & & $\begin{array}{l}\text { Path } \\
\text { coef }\end{array}$ & $\begin{array}{l}\text { z- } \\
\text { value }\end{array}$ & $\mathrm{p}$-value & $\begin{array}{l}\text { Path } \\
\text { coef }\end{array}$ & $\begin{array}{l}z- \\
\text { value }\end{array}$ & p-value & $\begin{array}{l}\text { Path } \\
\text { coef }\end{array}$ & $\begin{array}{l}z- \\
\text { value }\end{array}$ & p-value \\
\hline $\mathrm{H}_{1}$ & $\mathrm{BC} 1->\mathrm{SW} 1$ & -3.0571 & -5.27 & $0.000 * * *$ & 7.3051 & 3.12 & $0.002 * * *$ & 4.2300 & 1.76 & $0.078^{*}$ \\
\hline $\mathrm{H}_{1}$ & BC2 -> SW1 & 0.2258 & 4.94 & $0.000 * * *$ & -0.0281 & -0.15 & 0.877 & 0.1978 & 1.05 & 0.292 \\
\hline $\mathrm{H}_{1}$ & BC3 -> SW1 & -0.0852 & -0.11 & 0.910 & -1.7428 & -0.58 & 0.562 & -1.828 & -0.59 & 0.555 \\
\hline $\mathrm{H}_{1}$ & BC4 -> SW1 & -0.3459 & -0.23 & 0.819 & -1.2195 & -0.20 & 0.840 & -1.5654 & -0.25 & 0.802 \\
\hline $\mathrm{H}_{1}$ & $\mathrm{BC} 1->\mathrm{SW} 2$ & -14.212 & -0.76 & 0.446 & 27.929 & 2.07 & $0.038^{* *}$ & 13.7169 & 0.62 & 0.534 \\
\hline $\mathrm{H}_{1}$ & $\mathrm{BC} 2$-> SW2 & 3.6928 & 2.52 & $0.012 * * *$ & -0.1073 & -0.15 & 0.878 & 3.5854 & 2.21 & $0.027 * *$ \\
\hline $\mathrm{H}_{1}$ & $\mathrm{BC} 3$-> SW2 & -21.267 & -0.88 & 0.377 & -6.6631 & -0.57 & 0.570 & -27.931 & -1.03 & 0.301 \\
\hline $\mathrm{H}_{1}$ & BC4 -> SW2 & 177.93 & 3.69 & $0.000 * * *$ & -4.6622 & -0.20 & 0.840 & 173.276 & 3.23 & $0.001 * * *$ \\
\hline $\mathrm{H}_{2}$ & $\mathrm{BC} 1$-> DP1 & 1.7537 & 3.15 & $0.002 * * *$ & - & - & - & 1.7537 & 3.15 & $0.002 * * *$ \\
\hline $\mathrm{H}_{2}$ & BC2 -> DP1 & -0.0067 & -0.15 & 0.877 & - & - & - & -0.0067 & -0.15 & 0.877 \\
\hline $\mathrm{H}_{2}$ & BC3 -> DP1 & -0.4184 & -0.58 & 0.562 & - & - & - & -.04184 & -0.58 & 0.562 \\
\hline $\mathrm{H}_{2}$ & BC4 -> DP1 & -0.2928 & -0.20 & 0.840 & - & - & - & -0.2928 & -0.20 & 0.840 \\
\hline $\mathrm{H}_{3}$ & DP1-> SW1 & 4.1655 & 23.05 & $0.000 * * *$ & - & - & - & 4.1655 & 23.05 & $0.000 * * *$ \\
\hline $\mathrm{H}_{3}$ & DP2 -> SW1 & 0.9004 & 21.3 & $0.000 * * *$ & - & - & - & 0.9004 & 21.3 & $0.000 * * *$ \\
\hline $\mathrm{H}_{3}$ & DP3-> SW1 & -1.1241 & -12.5 & $0.000 * * *$ & - & - & - & -1.1241 & -12.5 & $0.000 * * *$ \\
\hline $\mathrm{H}_{3}$ & DP1 -> SW2 & 15.9255 & 2.76 & $0.006 * *$ & - & - & - & 15.9255 & 2.76 & $0.048 * *$ \\
\hline $\mathrm{H}_{3}$ & DP2 -> SW2 & 3.0094 & 2.22 & $0.026^{*}$ & - & - & - & 3.0094 & 2.22 & $0.026 * *$ \\
\hline $\mathrm{H}_{3}$ & DP3 -> SW2 & -7.6354 & -2.66 & $0.008 * * *$ & - & - & - & -7.6354 & -2.66 & $0.008^{* * *}$ \\
\hline DV & \begin{tabular}{ll} 
EPS & $\mathrm{mc}(\mathrm{R}$ \\
& $\mathrm{mc}^{2}$ \\
MPS & $\mathrm{mc}^{2}(\mathrm{R}$ \\
& $\mathrm{mc}^{2}$ \\
DPR & $\mathrm{mc}(\mathrm{R}$ \\
\multicolumn{1}{c}{$\mathrm{mc}^{2}$} \\
Overall $\mathrm{R}^{2}$ \\
OBS \\
VIF mean \\
Prob $>\mathrm{Chi}^{2}$
\end{tabular} & $\begin{array}{l}\text { Adj. } R^{2} \text { ) } \\
{ }^{2} \text { ) } \\
\text { Adj. } R^{2} \text { ) } \\
\text { () } \\
\text { Adj. } R^{2} \text { ) }\end{array}$ & & & & & & & & $\begin{array}{l}0.98 \\
0.96 \\
0.58 \\
0.34 \\
0.14 \\
0.02 \\
0.89 \\
561 \\
2.73 \\
0.000^{* * *}\end{array}$ \\
\hline
\end{tabular}

Source: Computation using STATA 13 . Note $*, * *, * *$ indicate significance levels at $10 \%, 5 \% \& 1 \%$ respectively.

The p-value of the model of 0.0000 shows that the relationship between board characteristics, dividend policy and shareholders' wealth of the sampled listed manufacturing firms is statistically significant. More so, the estimation Log likelihood (F-Statistics) value of 1594.85 indicate that the model of the study is well fit and as such the variables in the model were properly selected, combined and used. It also implies that the relationship between the dependent variable and the independent variables is not due to chance as the outcome and inferences made from the findings could be relied upon by $99 \%$ base on the significance level of $1 \%$ that is Prob $>$ chi $^{2}=0.0000$. As such the p-value of Prob $>$ chi $^{2}$ is statistically significant at $1 \%$ which means that dependent variables is reliably predicted by its predictors.

The model accounts for an overall $\mathrm{R}^{2}$ of 0.89 , this shows the extent of association between independent variables, mediator variables and dependent variables. This implies that of $89 \%$ of the total variation in shareholders' wealth could be explained by the explanatory variables board composition, board gender, board size, board ownership and mediator variables dividend payout ratio, dividend per share and dividend yield.

The effects of Board Characteristics on Shareholders' Wealth, the estimate records $\mathrm{R}^{2}$ of $98 \%$ which indicates the extent to which the independent variables explained dependent variable. Only $2 \%$ are responsible for factors not captured in this model. The adjusted $\mathrm{R}^{2}$ shows that the explained variable can further be explained by the explanatory variable by $96 \%$ leaving an error of $4 \%$ this shows that its 
strength, its applicability and its usefulness of this model in ascertaining the extent to which the direct as well as indirect effect of board characteristics on shareholders wealth of listed manufacturing companies in Nigeria through mediation of dividend policy is strong.

The effects of Board Characteristics on Dividend Policy, the estimate records a weak $\mathrm{R}^{2}$ of $14 \%$ which indicates the extent to which the independent variables explained dependent variable dividend per share. $86 \%$ accounts for factors not captured in this model. The adjusted $\mathrm{R}^{2}$ shows that the explained variable con still be explained by the explanatory variable by $2 \% \%$ leaving an error of $98 \%$ this shows the strength, its applicability and its usefulness of the model in ascertaining the extent to which the direct as well as indirect effect of board characteristics on shareholders wealth of listed manufacturing companies in Nigeria through mediation of dividend policy.

The effects of Dividend Policy on Shareholders' Wealth, the estimate records $\mathrm{R}^{2}$ of $58 \%$ which indicates the extent to which the independent variables explained dependent variable market price per share. Only $42 \%$ are responsible for factors not captured in this model. The adjusted $\mathrm{R}^{2}$ shows that the explained variable con still be explained by the explanatory variable by $34 \%$ leaving an error of $66 \%$. This shows that the strength, its applicability and its usefulness of the model in ascertaining the extent to which the direct as well as indirect effect of board characteristics on shareholders wealth of listed manufacturing companies in Nigeria through mediation of dividend policy is relatively low.

\section{Board Composition and Shareholders' Wealth (Earnings per Share)}

Table 4.3 shows that board composition on earnings per share have direct pathway coefficient and zvalue of -3.075 and -5.27 respectively with significant value of 0.000 , Indirect pathway coefficient and $z-$ value of 7.305 and 3.12 respectively with significant value of 0.002 and total effect coefficient and $\mathrm{z}$ value of 4.166 and 1.76 respectively with significant value of 0.078 . This connotes that board composition has a negative significant direct effect on earnings per share of listed manufacturing companies at $1 \%$ level of significance with a positive indirect effect at $1 \%$. The positive indirect effect via mediators' acts to lessen the otherwise stronger negative effect of board composition on earnings per share. The opposite significant signs combine to produce a positive total effect of board composition on earnings per share. This implies that an increase in the proportion of non - executive directors to total directors on the board will increase earnings per share of listed manufacturing companies in Nigeria by $1 \%$ when dividend is used. Hence, the positive effect of board composition on earnings per share is completely due to the indirect mechanism operating through the mediator. Since the indirect effect acts to reduce the strong negative direct effect, then it's concluded that a partial mediation exist in this case. This positive and significant result is in accordance with theory of Jensen (1986) which encouraged reduction of cash flow through payment of dividend. However, dividend acts as a valuable tool in improving the shareholders wealth. This result confirms the existing literature on this phenomena and therefore the study fail to reject the research hypotheses that board composition affect shareholders' wealth (earnings per share) of listed manufacturing companies in Nigeria. This findings is in line with the studies of Johl, Kaur and Cooper (2015) Ayesha, Chathurika, Kumarihami, Sagarika, Nanayakkara and Abeywardane (2015) who found negative effect of board composition and shareholders wealth. And the result of Sayumwe and Amroune (2015), Meyer and Wet (2014) and Yusoff and Adamu (2012), who found positive effect.

\section{Board Size and Shareholders' Wealth (Earnings per Share)}

Board size and earnings per share was observed to have path coefficient and z-value of 0.226 and 4.94 respectively with significant value of 0.000 , indirect pathway coefficient and z-value of -0.028 and 0.15 respectively with significant value of 0.877 and total effect coefficient and z-value of 0.198 and 1.05 respectively with significant value of 0.292 . This suggests that board size has significant positive direct effect on earnings per share of listed manufacturing companies at $1 \%$ level of significance, which implies that one increase in the number of directors sitting on the board increase earnings per share of listed manufacturing companies in Nigeria by $1 \%$. However, the indirect effect of board size on earnings per share is negative and statistically insignificant with a positive insignificant total effect. Though, the indirect effect is not significant but the opposite signs effect is felt in the total effect as the strength of the 
coefficient reduced significantly, therefore partial mediational is observed here. This study fail to reject the research hypotheses that board affect size shareholders' wealth (earnings per share) of listed manufacturing companies in Nigeria. This findings is in line with the studies of Shittu, Ahmed and Ishak (2016), Oyerogba, Memba and Riro (2016), Haider, Khan, Al-sufy and Iqbal (2015), Malik and Wan (2014), However, this result is contrary to the result of Ashraf, Iqbal and Tariq (2016) and Adebayo, Ayeni and Oyewole (2013) who found negative effect.

\section{Board Ownership and Shareholders' Wealth (Earnings per Share)}

Board ownership and earnings per share was observed to have path coefficient and z-value of -0.085 and -0.11 respectively with $p$-value of 0.910 , indirect pathway coefficient and z-value of -1.743 and -0.58 respectively with significant value of 0.562 and total effect coefficient and z-value of -1.828 and -0.59 respectively with significant value of 0.555 . This suggests that board ownership has a negative insignificant effect on earnings per share which means board ownership does not affect earnings per share of listed manufacturing companies in Nigeria. There is an element of mediation, in that the strength of the coefficient reduced significantly, therefore partial mediational is observed here. This is in line with the study of Chandren Ahmad and Ali (2015) who found a negative insignificant effect of board ownership and earnings per share.

\section{Board Gender and Shareholders' Wealth (Earnings per Share)}

Board gender and earnings per share was observed to have path coefficient and z-value of -0.346 and -0.23 respectively with p-value of 0.819 , indirect pathway coefficient and z-value of -1.219 and -0.20 respectively with p-value of 0.840 and total effect coefficient and z-value of -1.565 and -0.25 respectively with p-value of 0.802 . This suggests that board gender has a negative insignificant effect on earnings per share which means board gender does not determine earnings per share of listed manufacturing companies in Nigeria. There is an element of mediation, in that the strength of the coefficient reduced significantly, therefore partial mediational is observed here. This is in line with the study of Cheema and Din (2013) and Ahmed and Hamdan (2015) who found insignificant effect of board gender and earnings per share.

\section{Board Composition and Shareholders' Wealth (Market Price per Share)}

This study observe that board composition on market price per share have direct pathway coefficient and $z$-value of -14.212 and -0.76 respectively with significant value of 0.446 , indirect pathway coefficient and z-value of 27.929 and 2.07 respectively with significant value of 0.038 and total effect coefficient and z-value of 13.717 and 0.62 respectively with significant value of 0.534 . This indicates that the board composition has a negative insignificant direct effect on market price per share, with a significance positive indirect effect on market price per share of listed manufacturing companies at $5 \%$ level of significance. The opposite signs combine to produce a positive insignificant total effect of board composition on market price per share, this indicates that the inclusion of mediators improves the association between board composition and market price per share meaning that an increase in the proportion of non- executive directors to total directors on will increase market price per share of listed manufacturing companies in Nigeria by $3.8 \%$. Since the direct effect is not significant and the strength of the coefficient of indirect effect increase significantly, then no mediation exist in this case. This result contradicts the existing literature on this phenomena and therefore the study reject the research hypotheses that dividend policy mediates the relationship between board composition and shareholders' wealth (earnings per share) of listed manufacturing companies in Nigeria. This findings contradicts the studies of Samontaray (2010), found positive effect of board Composition on market price per share. However, Sayumwe and Amroune (2017) and Dobbin \& Jung (2008) found negative effect of board Composition on market price per share. 


\section{Board Size and Shareholders' Wealth (Market Price per Share)}

Board size was found to have positive significant direct effect on shareholders' wealth market price per share at 1\% level of significance accompanied by path coefficient and z-value of 3.693 and 2.52 respectively with p-value 0.012 . The indirect pathway coefficient and z-value of -0.107 and -0.15 respectively with significant value of 0.878 and total effect coefficient and z-value of 3.585 and 2.21 respectively with significant value of 0.027 . This suggests that board size has significant positive direct effect on market price per share of listed manufacturing companies at $1 \%$ level of significance. This implies that as board size increases, shareholders' wealth of listed manufacturing companies in Nigeria increases by $1 \%$. However, the indirect effect of board size on market price per share is negative and statistically insignificant which combine to produce positive significant total effect. Since the indirect effect is not significant, though the opposite signs effect is felt in the total effect, there is partial mediational effect in this case. This confirms theory of Jensen (1986) which encouraged reduction of cash flow through payment of dividend. In this case, dividend does not acts as a valuable tool in improving the shareholders wealth. Therefore the study fail to reject the research hypotheses that dividend policy mediates the relationship between board size and shareholders' wealth (market price per share) of listed manufacturing companies in Nigeria. This findings is in line with the studies of Ferrer and Banderlipe, (2012) found insignificant effect of board Size on market price per share. However, this result is contrary to the result of Dobbin and Jung (2008) and Sayumwe and Amroune (2017) found positive effect of board Size on market price per share.

\section{Board Ownership and Shareholders' Wealth (Market Price per Share)}

Board ownership and market price per share was observed to have path coefficient and z-value of 21.267 and -0.88 respectively with p-value of 0.377 , indirect pathway coefficient and z-value of -6.663 and -0.57 respectively with significant value of 0.570 and total effect coefficient and z-value of -27.931 and -1.03 respectively with significant value of 0.301 . This suggests that board ownership has a negative insignificant effect on market price per share which means board ownership does not determine market price per share of listed manufacturing companies in Nigeria. There is no element of mediation, in that the strength of the coefficient increased significantly, therefore no mediation is observed here. This is in line with the study of Ferrer and Banderlipe, (2012) and Sayumwe and Amroune (2017) found insignificant effect of board ownership on market price per share.

\section{Board Gender and Shareholders' Wealth (Market Price per Share)}

Board gender was found to have positive and significant effect on shareholders' wealth market price per share at $1 \%$ level of significance. This is accompanied by path coefficient and z-value of 177.94 and 3.69 respectively with p-value 0.000 . The indirect pathway coefficient and z-value of -4.662 and -0.20 respectively with insignificant value of 0.840 and total effect coefficient and z-value of 173.276 and 3.23 respectively with significant value of 0.001 . The positive direct effect implies that shareholders' wealth increases, when the proportion of female sitting on the board of listed manufacturing companies increases by $1 \%$. Meaning that the more the women on the board the more improvement in financial decision, and greater dividend payout which improve the wealth of the shareholders of listed manufacturing companies in Nigeria. However, the indirect effect of board gender on market price per share is negative and statistically insignificant which combine to produce a positive significant total effect at $1 \%$. The indirect effect is negative and not significant which reduces the strength of the coefficient of significant, there is partial mediational effect in this case. This negative insignificant indirect effect contradicts existing study that board gender is associated with firm's tendency to pay or increase dividend because when board is diversified with female directors, strategy decision will be less aggressive and more risk averse which in turn improve shareholders' wealth. In this case, dividend does not acts as a valuable tool in improving the shareholders wealth. This findings is in line with the studies of Ferrer \& Banderlipe, (2012) and Ferrari, Ferraro, Profeta \& Pronzato (2018) found positive effect of board gender on market price per share. However, Dobbin \& Jung (2008) found negative effect of board gender on market price per share. 


\section{Board Composition and Dividend Policy (Dividend Payout Ratio)}

Board composition was found to have positive and significant effect on dividend policy-dividend payout ratio at $1 \%$ level of significance. This is accompanied by path coefficient and z-value of 1.754 and 3.15 respectively with p-value 0.002 . This suggests that dividend policy increases, when there is an increase in the board composition of listed manufacturing companies. This implies that an increase in the proportion of non- executive directors to total directors on will increase dividend payout ratio of listed manufacturing companies in Nigeria by $1 \%$. This result confirms the theory which suggest the inclusion of non-executive independent directors on the board to mitigate agency related problems and minimize agency costs. Therefore, concludes that board composition improves dividend policy. This study fail to reject the research hypotheses that board composition affect dividend policy of listed manufacturing companies in Nigeria. This findings is in line with the studies of Farinha (2002) and Mansourinia, Emamgholipour, Rekabdarkolaei and Hozoori (2013), Al-Rahahleh (2017) found positive significant effect on the two construct. However, Gawad, Sakr and Soliman (2013) Mansourinia, Emamgholipour, Rekabdarkolaei \& Hozoori (2013) provide negative significant effect on the two construct.

\section{Board Size and Dividend Policy (Dividend Payout Ratio)}

Board size was found to have negative insignificant effect on dividend policy-dividend payout ratio. This is accompanied by path coefficient and z-value of -0.007 and -0.15 respectively with p-value 0.877 . This suggests that board size do not determine dividend policy of listed manufacturing companies in Nigeria. This study reject the research hypotheses that board size affect dividend policy of listed manufacturing companies in Nigeria. This findings is in line with the studies of Wellalage, Fauzi and Wang (2006) and Gawad, Sakr and Soliman (2012) who found insignificant effect of board size on dividend payout ratio. Contrary to this result is the result of Ogbechie and Koufopoulos (2010), Gill and Obradovich (2012), Ada (2013), and Kurawa and Ishaku (2014) who found positive significant effect on the two construct. However, Odeleye (2017) and Batool and Javid (2014) found negative effect of board size on dividend payout ratio.

\section{Board Ownership and Dividend Policy (Dividend Payout Ratio)}

Board ownership was found to have positive and significant effect on dividend policy-dividend payout ratio at $1 \%$ level of significance. This is accompanied by path coefficient and z-value of -0.418 and -0.58 respectively with p-value 0.562 . This suggests that dividend policy increases, when there is an increase in the board ownership of listed manufacturing companies. This implies that board ownership do not affect dividend payout ratio of listed manufacturing companies in Nigeria. This study reject the research hypotheses that board ownership affect dividend policy of listed manufacturing companies in Nigeria. This findings is in line with the studies of Kunga (2012) and Odia and Ogiedu (2013) who found insignificant effect of board ownership on dividend payout ratio. Contrary to this study is the study of Harvath \& Spirollari (2012) Kumar (2004), Abdelsalam, El-Masry and Elsegini (2008), Al-Rahahleh (2009) who found positive effect of board ownership on dividend payout ratio. However, Ikuna, Muiru, Kamau (2016) Aydin and Cardar (2015), Ekanayake and Paranthaman (2015) and Pelt (2013) who found negative effect of board ownership on dividend payout ratio.

\section{Board Gender and Dividend Policy (Dividend Payout Ratio)}

Board gender was found to have positive and significant effect on dividend policy-dividend payout ratio at $1 \%$ level of significance. This is accompanied by path coefficient and z-value of -0.293 and -0.20 respectively with p-value 0.840 . This suggests that dividend policy increases, when there is an increase in the board gender of listed manufacturing companies. This implies that board gender do not affect dividend payout ratio of listed manufacturing companies in Nigeria. This study reject the research hypotheses that board gender affect dividend policy of listed manufacturing companies in Nigeria. This findings is in line with the studies of Harvath and Spirollari (2012). However, this study contradicts the study of Dao, Brown \& Hsu (2015), Chen, Leung and Goergen (2016) and Elmagrhi, Ntimi, Crossley, 
Malagila Fosu and Vu (2017) found positive effect of board gender on dividend payout ratio. And Bolbol (2012) who negative effect of board gender on dividend payout ratio.

\section{Dividend Payout Ratio and Shareholders' Wealth (Earnings per Share)}

Dividend payout ratio was found to have positive and significant effect on shareholders' wealth earnings per share at $1 \%$ level of significance with path coefficient and z-value of 4.166 and 23.05 respectively with p-value 0.000 . This implies that shareholders' wealth increases, when dividend payout ratio increases. Meaning that an increase dividend payout ratio does increase earnings per share of listed manufacturing companies in Nigeria by 1\%. This result confirms the existing literature on this phenomena as payout ratios have tremendous prediction power on the shareholders' wealth. Therefore this study fail to reject the research hypotheses that dividend payout ratio affect shareholders' wealth (earnings per share) of listed manufacturing companies in Nigeria. This findings is in line with the studies of Hasan, Ahmad, Rafiq, Rehman (2015), Hunjra, Ijaz, Chani, Hassan and Mustafa (2014) and Balagobei (2015) found positive effect of dividend payout ratio on earnings per share. However, Thafanil and Abdullah (2014) and Epaphra and Nyantori (2018) who found negative effect of dividend payout ratio on earnings per share.

\section{Dividend per Share and Shareholders' Wealth (Earnings per Share)}

Dividend per share was found to have positive and significant effect on shareholders' wealth earnings per share at $1 \%$ level of significance which is accompanied by path coefficient and z-value of 0.9005 and 21.28 respectively with p-value 0.000 . This implies that shareholders' wealth increases, when dividend per share increases. This implies that an increase in dividend per share does increase shareholders' wealth of listed manufacturing companies in Nigeria by $1 \%$. This result confirms the fact that company's investors receive value through dividend payments and the price of the stock itself, which is equal to a company's total expected future dividend payments. Hence, a company's profits, and the amount it pays out as dividends drives shareholder wealth. Increasing dividend per share is a great way for a company to signal strong performance to its shareholders. This result confirms the existing literature on this phenomena and therefore the study fail to reject the research hypotheses that dividend per share does not affect shareholders' wealth (earnings per share) of listed manufacturing companies in Nigeria. This findings is in line with the studies of Chaudhry, Boldin, Affaneh and Tickell (2015) and Balagobei (2015) found positive effect of dividend per share on earnings per share.

\section{Dividend Yield and Shareholders' Wealth (Earnings per Share)}

Dividend yield was found to have negative and significant effect on shareholders' wealth earnings per share at $1 \%$ level of significance. This is accompanied by path coefficient and z-value of -1.124 and 12.51 respectively 0.000 . This suggests that shareholders' wealth decreases, when dividend yield increases. This study fail to reject the research hypotheses that dividend yield does not affect shareholders' wealth (earnings per share) of listed manufacturing companies in Nigeria. This findings is in line with the studies of Epaphra and Nyantori (2018) found negative effect of dividend yield on earnings per share. However, Hunjra, Ijaz, Chani, Hassan and Mustafa (2014) found positive effect of dividend yield on earnings per share.

\section{Dividend Payout Ratio and Shareholders' Wealth (Market Price per Share)}

Dividend payout ratio was found to have positive and significant effect on shareholders' wealth earnings per share at $1 \%$ level of significance with path coefficient and z-value of 15.926 and 2.76 respectively. This implies that shareholders' wealth (market price per share) increases, when dividend payout ratio increases. Meaning that an increase dividend payout ratio does increase shareholders' wealth of listed manufacturing companies in Nigeria by $1 \%$. This study fail to reject the research hypotheses that dividend payout ratio affect shareholders' wealth (market price per share) of listed manufacturing companies in Nigeria. This findings is in line with the studies of Kapoor (2009), Hassan, Asaduzzaman and Karim (2013), Makaya, Nyang'ara and James (2013) and Alim, Ali, Ali, Khattak and Qureshi (2014) 
found positive effect of dividend payout ratio on market price per share. However, Suwabe (2006) and Balagobei and Selvaratnam (2016) who found negative effect of dividend payout ratio on market price per share.

\section{Dividend per Share and Shareholders' Wealth (Market Price per Share)}

Dividend per share was found to have positive and significant effect on shareholders' wealth market price per share at 5\% level of significance which is accompanied by path coefficient and z-value of 3.009 and 2.22 respectively. This implies that shareholders' wealth increases, when dividend per share increases. Meaning that an increase in dividend per share does increase shareholders' wealth of listed manufacturing companies in Nigeria by $1 \%$. This result confirms the fact that company's investors receive value through dividend payments and the price of the stock itself, which is equal to a company's total expected future dividend payments. Hence, a company's profits, and the amount it pays out as dividends drives shareholder wealth. Increasing dividend per share is a great way for a company to signal strong performance to its shareholders. This study fail to reject the research hypotheses that dividend per share affect shareholders' wealth (earnings per share) of listed manufacturing companies in Nigeria. This findings is in line with the studies of Travlos and Trigeorgis Vafeas (2001), Azhagaiah and Sabari Priya (2008), Hassan, Asaduzzaman and Karim (2013), Sarwar (2013), Alim, Ali, Ali, Khattak and Qureshi (2014), Mathew, Innocent and Mike (2014), Sarwar and Naseem (2014) and Gejalakshmi Azhagaiah (2015) and Iram (2015) found positive effect of dividend per share on market price per share. However, Hussain (2010) who found negative effect of dividend per share on market price per share.

\section{Dividend Yield and Shareholders' Wealth (Market Price per Share)}

Dividend yield was found to have positive and significant effect on shareholders' wealth market price per share at $1 \%$ level of significance as indicated in the table above. This is accompanied by path coefficient and $z$-value of -7.635 and -2.66 respectively with $p$-value 0.008 . This implies that shareholders' wealth decreases, when dividend yield increases. Meaning that an increase in dividend yield decreases market price per share. This result contradicts the existing literature on this phenomena and though the study fail to reject the research hypotheses that dividend yield does not affect shareholders' wealth (market price per share) of listed manufacturing companies in Nigeria. This findings is in line with the studies of Ponsian, Prosper, Yuda \& Samwel (2015) who found negative effect of dividend yield on market price per share. However, Wet and Mpinda (2013), Al-Masum (2014), Bilal and Jamil (2015) and Gejalakshmi and Azhagaiah (2015) found positive effect of dividend yield on market price per share.

The implication of this findings is that dividend policy can be used to reduced agency cost as posit by Jensen (1986). Therefore, there is a possibility of optimizing shareholders wealth if the cash flow in the sampled firms is reduced through increases dividend payment. This will reduced the possibility of involving in wasteful investments. The contribution of this study is into two folded; First, board characteristics is considered as the way to improving shareholders wealth (Hart, 1995; Fama and Jensen, 1983) and it is also considered as a way of improving shareholders trust and confidence and protecting the shareholders wealth (Nicholson \& Kiel, 2007).

\section{CONCLUSION AND RECOMMENDATION}

Based on the findings it's concluded that, as provided by both empirical as well as statistical evidence on the use of dividend payment to mitigate agency problem and boost shareholders' wealth. This is because dividend policy mediates the relationship between board composition, board size, board ownership and board gender and shareholders' wealth (earnings per share). With respect to board composition, board ownership and board gender on shareholders' wealth (market price per share) no mediational effect except board size and market price per share of listed manufacturing companies in Nigeria. However, the mediation effect shows that dividend policy can be used to improve shareholders' wealth. It's therefore recommended that, listed manufacturing companies in Nigeria can restructure their 
dividend policies for the improvement of shareholders' wealth as this would help attract more investors to invest in the company which means more fund.

On the issues of appointment of directors of manufacturing firms, management should consider inclusion of more non-executive directors on the board in order to enhance the quality of decision especially that of financial in nature as this affect shareholders' wealth. The number of non-executive director should be increased to an average sixty percent $60 \%$ by management to ensure better monitors against the executive directors and hence this will improve shareholders' wealth.

The regulators such as security and exchange commission should make sure that the percentage of shares held by directors should not exceed $15 \%$ of the entire shares held to prevent directors having excessive power which may override the interest of other shareholders.

The number of women director should be increased to an average fifteen percent $15 \%$ by management to ensure better and continuous quality of financial decision and hence this will improve shareholders' wealth.

The number of directors on the board should be reduced to maximum of twelve (12) for manufacturing companies. Also, emphases should be on the quality of members on the board rather than just the size.

\section{ACKNOWLEDGEMENT}

We wish to thank Professor Kabiru Isa Dandago, Professor Tijani Bashiru, Professor Junaidu Muhammad Kurawa, Professor Kabir Tahir Hamid, Dr. Rabiu Ado and conference and colloquium participants at the Faculty of social and management sciences, Bayero University Kano, the $2^{\text {nd }}$ International conference and doctoral colloquium 2018 for their helpful suggestions and comments.

\section{REFERENCES}

Abdullah, S.N. (2004). Board composition, CEO duality, and performance among Malaysian listed companies. Corporate Governance Journal, 4(4), 47- 61.

Ada, B. A (2013). Relationship between corporate governance practices and dividend payout of commercial banks in Kenya. International Journal of Academic Research in Accounting, Finance and Management Sciences, 4, 11-90.

Adebayo O.S., Ayeni, G.O., \& Oyewole, F.A. (2013). Relationship between corporate governance and organizational performance: Nigerian listed organizations experience. International Journal of Business and Management Invention, 2(9), 2319 - 8028.

Ahmed, E., \& Hamdan, A. (2015). The impact of corporate governance on firm performance: evidence from the Bahrain stock exchange. European Journal of Business and Innovation Research, 3(5), 25-48.

Akande, O. (2016). Corporate governance issues in the Nigerian banking industry. Unpublished Doctoral dissertations. Walden University.

Ali, R., Liu, Y., \& Niazi. G.R. (2017). Corporate governance and performance of peer firms: a crosslagged analysis of an emerging economy. The Journal of Applied Business Research, 33(3).

Ayesha, P. V., Chathurika, P.K.A.G., Kumarihami, H.M.D.A., Sagarika, D.B.T., Senanayaka, C., \& Sewwandi, R.M.S. (2015). Corporate governance and earnings per shares: a study of Sri Lankan manufacturing companies. Journal of Financial Management, 1(1), 201-210.

Azar, A., Rad, F.H., \& Botyari, E. (2014). Board characteristics and firm performance: Malaysian Evidence. Quest Journals, Journal of Research in Business and Management, 2(6), 28-34.

Azeez, A.A. (2015). Corporate governance and firm performance: Evidence from Sri Lanka. Journal of Finance and Bank Management, 3(1), 180-189.

Azhagaiah, R., \& SabariPriya, N. (2008). The impact of dividend policy on shareholders' wealth. International Research Journal of Finance and Economics, (20), 181-187. 
Bathula, H. (2008). Board characteristics and firm performance: Evidence from New Zealand. Unpublished Ph.D. thesis, Auckland University of Technology, New Zealand.

Bolbol, I.I. (2012). Board characteristics and dividend payout of Malaysian companies. Journal of Business Management, 6(29), 496-503.

Borokhovich, K., Parrino R., \& Trapani, T. (1996). Outside directors and CEO selection. Journal of Financial and Quantitative Analysis, 31, 337-355.

Carter, D.A., Simkins, B. J., \& Simpson, W.G. (2003). Corporate governance, board diversity, and firm value. The Financial Review, 38, 33 - 53.

Chandren, S., Ahmad Z., \& Ali, R. (2015). Corporate governance mechanisms and accretive share buyback to meet or beat earnings per share forecast. International Journal of Business and Society, 16(3), 344 - 363.

Cheema, K.R., \& Din, M.S. (2013). Impact of corporate governance on the performance of firms: a case study of the cement industry in Pakistan. Journal of Business and Management Sciences, 1(4), 44-46.

Chenchehene, J., \& Mensah, K. (2015) Dividend policy and its effects on shareholders wealth: Evidence from the UK retail industry. International Journal of Liberal Arts and Social Science, 52(2), 2307-2324.

Dewet, J., \& Mpinda, M. (2013). Impact of dividend payments on shareholders' wealth: Evidence from the vector correction model. International Business and Economics, Research Journal, 12(11), 1451-1465.

Elangkumara P., \& Jenitta, J.N. (2012). The Impact of Dividend Policy on Shareholders' Wealth - A study of Colombo Stock Exchange CSE in Sri Lanka. Journal of Asia Business Studies, 6(1), 79-92.

Fama, E.F., \& Jensen, M.C. (1983). Separation of ownership and control. Journal of Law and Economics, 26(2), 301- 325

Faramarzi, M., \& Amini, H. (2016). The impact of corporate governance on the relationship between investment opportunities and dividend policy division. International Academic Journal of Economics, 3(6), 22-35.

GejaLakshmi, S., \& Azhagaiah, R. (2015). The impact of dividend policy on shareholders' wealth before and after the financial meltdown: evidence from the FMCG sector in India. Financial Risk and Management Reviews, 1(1), 8-26.

Ghabayen, M.A. (2012). Board characteristics and firm performance: Case of Saudi Arabia. International Journal of Accounting and Financial Reporting, 2, 168-200.

Ghosh, S. (2006). Do board characteristics affect corporate performance: firm-level evidence for India. Journal of Applied Economics Letters, 13(7), 435-43.

Ghosh C., \& Sirman C.F. (2003). Board Independence, ownership structure and performance: Evidence from real estate investment trust. Journal of Real Estate Finance and Economics, 26(2-3), $287-$ 318.

Haider, N., Khan, N., \& Iqbal, N. (2015). Impact of corporate governance on firm financial performance in Islamic financial institution. International Letters of Social and Humanistic Sciences, 51, 106110.

Hu, H.W., Tam, O.K., \& Tan, M.G.S. (2010). Internal governance mechanisms and firm performance in China. Asia Pacific Journal of Management, 27(4), 727-749.

Ikunda, C., Muiru, M., \& Kamau S.M. (2016).The Impact of corporate governance on dividend payout of manufacturing firms listed at the Nairobi securities exchange. Journal of Finance and Accounting, 4(5), 254-261.

Iram, F. (2010). The impact of dividend Policy on Shareholder's wealth. International Research for Finance and Economics, 20(15), 1-14.

Jensen, M. (1986). Agency costs of free cash flow, corporate finance, and takeovers. American Economic Review, 76(2), 323-329.

Jensen, M., \& Meckling, W. (1976). Theory of the firm: Managerial behavior, agency costs, and ownership structure. Journal of Financial Economics, 3(4), 305-360.

44 Journal of Applied Business and Economics Vol. 21(9) 2019 
Jensen, M.C. (1993). The modern industrial revolution, exit, and the failure of internal control systems. The Journal of Finance, 48, 831-880.

Johl, S.K., Kaur, S., \& Cooper, B.J. (2015). Board characteristics and firm performance: Evidence from Malaysian public listed firms. Journal of Economics, Business, and Management, 3(2), 1-5.

Kai, A.O.S., Shyuan, L.A., Yer L.M., Yee, O.Y.P., \& Lai, L.T. (2014). The impact of dividend policy on shareholders' wealth: evidence on Malaysia's listed food producer sector. Unpublished Ph.D. Thesis, Universiti Tunku Abdul Rahman.

Kumaresan, S. (2014). Impact of dividend policy on shareholders' wealth: A study of listed firms in hotels and travels sector of Sri Lanka. International Journal of Technological Exploration and Learning, 3(1), 349-352.

Li, M., \& He, H. (2013). A study on the role-path of independent directors in listed companies. Journal of the Shandong University of Finance, 123(1), 100-107.

Lipton, M., \& Lorsch, J. W. (1992). A modest proposal for improved corporate governance. The Journal of Business Lawyer, 48(2), 59-77.

Lu, Y.H. (2009). Study on Integrating Function of Independent Director. Retrieved from https://www.chn.global.cnki.net

Malik, M., Wan, D., Ahmad, M. I., Naseem, M.A., \& Rehman, R.U. (2014). Role of board size in corporate governance and firm performance applying the Pareto approach, is it cultural phenomena? The Journal of Applied Business Research, 5(2), 1395-1496.

Marinova, J., Plantenga, J., \& Remery, C. (2010), Gender diversity and firm performance: Evidence from Dutch and Danish boardrooms. Discussion Paper, University of Utrecht, Utrecht, 10(3).

Meyer, E., \& Wet, J. (2013). The impact of board structure on the financial performance of listed South African companies. Corporate board: Role, Duties and Composition, 9(3), 18-31.

Morck, R., Shleifer, A., \& Vishny, R.W. (1988). Management ownership and market valuation: An empirical analysis. Journal of Financial Economics, 20, 293-315.

Officer, M. S. (2006). Dividend policy, dividend initiations, and governance. Journal of Managerial Finance, 3(4), 53-64.

Omoregie, A. E., \& Eromosele, P.E (2016). Dividend policy and shareholders' wealth: Evidence from some quoted banks in Nigeria. International Journal of Marketing and Financial Management, $4(6), 55-72$.

Pelt, T.V. (2013). The effect of board characteristics on dividend policy. A Doctoral thesis, Tilburg University, Netherlands.

Shehu, N. (2015). Board characteristics and dividend payout: evidence from Malaysian public listed companies. Research Journal of Finance and Accounting, 6(16), 2222-1697

Sayumwe, M., \& Amroune, B. (2017). Directors' characteristics and stock market performance in Canada. Journal of Economic and Financial Studies, 05(01), 01-15.

Shittu, I., Ahmad, A.C., \& Ishak, Z. (2016). Board characteristics and earnings per share of Malaysian Islamic banks. International Journal of Economics and Financial Issues, 6(s6) 135 -137.

Subramaniam, R., \& Devi, S. S. (2011). Corporate governance and dividend policy in Malaysia. International Conference on Business and Economics Research, 1, 200-207.

Uwalomwa, U., Olamide, O., \& Francis, L. (2015). The effects of corporate governance mechanisms on firms dividend payout policy in Nigeria. Journal of Accounting and Auditing: Research \& Practice, 20(15), 1- 11.

Yarram, S.R. (2010). Board characteristics and dividend policy: Australian evidence. Doctoral Thesis, University of New England, Armidale NSW 2350 Australia.

Yusoff, W.F.W., \& Adamu, I.A. (2012). Corporate governance and firm performance of listed companies in Malaysia. Trends and Development in Management Studies, 1(1), 43-65. 